Научная статья

УДК 33.332.146.2

DOI 10.18101/2304-4446-2020-4-52-63

\title{
ВОСТОЧНЫЕ ТЕРРИТОРИИ РОССИИ: ДИСПРОПОРЦИИ РАЗВИТИЯ И МЕХАНИЗМЫ ГОСУДАРСТВЕННОЙ ПОДДЕРЖКИ
}

\section{(C) Дугаржапова Долгорма Баторовна}

кандидат экономических наук, старший научный сотрудник, Бурятский научный центр СО РАН Россия, 670047, г. Улан-Удэ, ул. Сахьяновой, 8 dolgor@mail.ru

Аннотация. В статье дан анализ основных макроэкономических показателей. Установлены неравенство и существенные диспропорции развития восточных территорий Российской Федерации. Выделены ключевые проблемы, обусловливающие возникновение диспропорций пространственного развития исследуемого макрорегиона. Отмечается, что существующие диспропорции определяют социальную напряженность в различных локально-территориальных общностях внутри регионов.

В качестве мер государственной поддержки экономического развития макрорегиона рассмотрены территории опережающего развития, эффективность их реализации. Отмечено, что формирующиеся тенденции и ориентиры потенциального развития исследуемых территорий свидетельствуют прежде всего о положительных сторонах проводимой политики в преобразовании территориально-отраслевой структуры хозяйства рассматриваемых регионов.

Показано, что сохранение оттока населения в большинстве дальневосточных регионов, высокие инфраструктурные затраты обусловливают необходимость дополнительных мер поддержки с уточнением подходов к организации системы расселения, развитию социальной инфраструктуры, транспорта и бюджетного финансирования с использованием механизмов межбюджетных субсидий.

Ключевые слова: Дальний Восток; Байкальский регион; социально-экономическое развитие; экономическая дифференциация; государственная поддержка; территории опережающего развития.

\section{Для цитирования}

Дугаржапова Д. Б. Восточные территории России: диспропорции развития и механизмы государственной поддержки // Вестник Бурятского государственного университета. Экономика и менеджмент. 2020. № 4. С. 52-63.

\section{Введение}

Реализация экономических интересов России в Азиатско-Тихоокеанском регионе требует сбалансированного экономического и демографического развития субъектов Дальнего Востока и Байкальского региона. В связи с этим используется широкий комплекс государственных мер для решения стратегических, экономических, социально-демографических проблем восточных территорий Российской Федерации (РФ). В то же время сохраняющееся отставание в техникотехнологической модернизации производства, имеющиеся инфраструктурные ограничения, социальное неблагополучие и отток населения обусловливают 
Д. Б. Дугаржапова. Восточные территории России: диспропорции развития и механизмы государственной поддержки

необходимость анализа результатов государственной политики на развитие исследуемого макрорегиона.

\section{Материалы и методы исследования}

В основе исследования лежат экономико-статистические методы, позволяющие объективно оценивать процессы регионального и внутрирегионального неравенства, дифференциации уровней социально-экономического развития восточных территорий РФ и эффективность реализации механизмов государственной поддержки. В анализе использованы данные государственной и ведомственной статистики.

Социально-экономические и бюджетно-финансовые показатели развития Дальнего Востока и Байкальского региона

Согласно данным «РИА Рейтинг» дальневосточные регионы за последние десять лет занимают недостаточно высокие позиции и существенно различаются по социально-экономическому положению (табл. 1).

Таблица 1

Рейтинг социально-экономического положения субъектов Дальнего Востока и Байкальского региона

\begin{tabular}{|c|c|c|c|c|c|c|c|c|}
\hline \multirow[b]{2}{*}{ Субъекты РФ } & \multicolumn{2}{|c|}{2010 г. } & \multicolumn{2}{|c|}{2015 г. } & \multicolumn{2}{|c|}{2018 г. } & \multicolumn{2}{|c|}{2019 г. } \\
\hline & 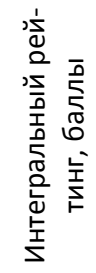 & 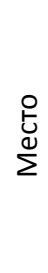 & 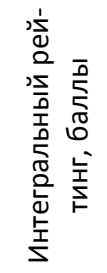 & 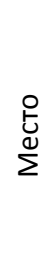 & 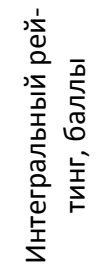 & 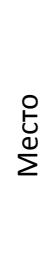 & 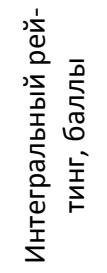 & $\stackrel{\circ}{\stackrel{\circ}{E}}$ \\
\hline Республика Саха (Якутия) & 52,33 & 22 & 53,103 & 21 & 45,427 & 32 & 45,835 & 33 \\
\hline Камчатский край & 36,30 & 56 & 36,521 & 57 & 24,413 & 75 & 25,325 & 76 \\
\hline Приморский край & 45,53 & 36 & 48,595 & 27 & 47,449 & 26 & 47,298 & 31 \\
\hline Хабаровский край & 50,09 & 27 & 46,956 & 33 & 39,973 & 42 & 41,622 & 44 \\
\hline Амурская область & 38,10 & 50 & 39,507 & 51 & 35,254 & 54 & 37,365 & 52 \\
\hline Магаданская область & 29,92 & 67 & 31,658 & 64 & 24,760 & 74 & 25,683 & 75 \\
\hline Сахалинская область & 53,80 & 18 & 62,917 & 7 & 54,611 & 19 & 57,064 & 19 \\
\hline $\begin{array}{l}\text { Еврейская автономная } \\
\text { область }\end{array}$ & 21,14 & 75 & 13,755 & 84 & 12,593 & 84 & 12,743 & 85 \\
\hline $\begin{array}{l}\text { Чукотский автономный } \\
\text { округ }\end{array}$ & 24,74 & 72 & 29,920 & 67 & 15,307 & 81 & 17,414 & 79 \\
\hline Республика Бурятия & 34,01 & 59 & 35,095 & 61 & 26,541 & 69 & 27,889 & 71 \\
\hline Забайкальский край & 33,65 & 60 & 29,393 & 69 & 27,059 & 66 & 28,884 & 67 \\
\hline Иркутская область & 47,11 & 31 & 50,719 & 25 & 49,690 & 23 & 51,251 & 22 \\
\hline
\end{tabular}

Источник: Данные РИА Рейтинг. URL: https://riarating.ru/ (дата обращения: 12.10.2020).

По приведенным данным, в 2019 г. выше 50-й позиции рейтинга расположились семь регионов исследуемого макрорегиона. Наиболее высокие позиции у Сахалинской и Иркутской областях с интегральным рейтингом выше 50 баллов (57,064 и 51,251 балла соответственно). В то же время Чукотский автономный округ (ЧАО) и Еврейская автономная область (ЕАО) занимают соответственно 
79 и 85 позиции с интегральными рейтингами ниже 20 баллов (17,414 и 12,743 балла соответственно). В целом по сравнению с 2018 г. изменения величины интегрального показателя варьировались от $-0,2$ до 2,5 балла. Вместе с тем существенных изменений позиций рассматриваемых регионов не произошло: на два места повысились позиции лишь у Амурской, Иркутской областей и ЧАО, у Сахалинской области позиции остались на прежнем уровне, на пять мест снизились позиции Приморского края, в остальных регионах снижение было незначительным (на 1-2 места).

Анализ основных показателей социально-экономического положения исследуемых субъектов макрорегиона показал, что в качестве негативных факторов можно выделить снижение доли прибыльных предприятий, сокращение численности занятых в экономике, повышение смертности населения в трудоспособном возрасте. К позитивным следует отнести увеличение объемов инвестиций, рост доходов консолидированного бюджета, снижение уровня безработицы (табл. 2).

Таблица 2

Рейтинг субъектов восточных территорий РФ по основным социально-экономическим показателям

\begin{tabular}{|c|c|c|c|c|c|c|c|c|c|c|}
\hline \multirow{2}{*}{ Регионы РФ } & \multicolumn{2}{|c|}{$\begin{array}{c}\text { Объем про- } \\
\text { изводства } \\
\text { товаров и } \\
\text { услуг на } 1 \\
\text { жителя } \\
\end{array}$} & \multicolumn{2}{|c|}{$\begin{array}{c}\text { Доходы кон- } \\
\text { солид. бюд- } \\
\text { жета на } 1 \\
\text { жителя }\end{array}$} & \multicolumn{2}{|c|}{$\begin{array}{c}\text { Инвестиции в } \\
\text { основной } \\
\text { капитал на } \\
\text { душу населе- } \\
\text { ния } \\
\end{array}$} & \multicolumn{2}{|c|}{$\begin{array}{c}\text { Численность } \\
\text { занятых в эко- } \\
\text { номике }\end{array}$} & \multicolumn{2}{|c|}{$\begin{array}{c}\text { Смертность } \\
\text { населения } \\
\text { трудоспо- } \\
\text { собного воз- } \\
\text { раста }\end{array}$} \\
\hline & $\begin{array}{l}\dot{0} \\
\frac{a}{2} \\
\dot{u} \\
\dot{r}\end{array}$ & $\begin{array}{l}\text { 놈 } \\
\text { 元 } \\
\stackrel{2}{2}\end{array}$ & $\begin{array}{l}\dot{0} \\
\frac{a}{2} \\
\dot{0} \\
\dot{1}\end{array}$ & 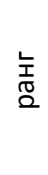 & $\begin{array}{l}\dot{0} \\
\grave{a} \\
\dot{u} \\
\dot{1}\end{array}$ & 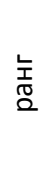 & 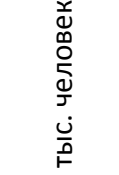 & 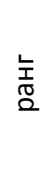 & 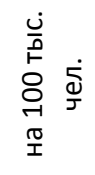 & $\begin{array}{l}\text { 놈 } \\
\text { 离 } \\
\text { 2 }\end{array}$ \\
\hline $\begin{array}{l}\text { Республика } \\
\text { Саха (Якутия) }\end{array}$ & 1335,11 & 4 & 56,88 & 12 & 393,52 & 4 & 466,13 & 5 & 457,6 & 12 \\
\hline $\begin{array}{l}\text { Камчатский } \\
\text { край }\end{array}$ & 743,84 & 5 & 57,33 & 11 & 150,65 & 6 & 174,47 & 9 & 566,2 & 10 \\
\hline $\begin{array}{l}\text { Приморский } \\
\text { край }\end{array}$ & 348,91 & 9 & 72,76 & 5 & 94,45 & 10 & 942,67 & 2 & 587,3 & 9 \\
\hline $\begin{array}{l}\text { Хабаровский } \\
\text { край }\end{array}$ & 492,94 & 7 & 70,60 & 8 & 122,49 & 8 & 673,92 & 3 & 595,6 & 8 \\
\hline $\begin{array}{l}\text { Амурская об- } \\
\text { ласть }\end{array}$ & 429,33 & 8 & 80,39 & 3 & 429,24 & 3 & 385,52 & 7 & 678,2 & 4 \\
\hline $\begin{array}{l}\text { Магаданская } \\
\text { область }\end{array}$ & 1655,29 & 3 & 66,68 & 9 & 254,39 & 5 & 81,21 & 10 & 690,5 & 2 \\
\hline $\begin{array}{l}\text { Сахалинская } \\
\text { область }\end{array}$ & 2437,43 & 1 & 206,32 & 1 & 473,78 & 2 & 258,86 & 8 & 599,3 & 7 \\
\hline $\begin{array}{l}\text { Еврейская } \\
\text { автономная } \\
\text { область }\end{array}$ & 297,15 & 10 & 71,29 & 6 & 97,33 & 9 & 72,62 & 11 & 680,6 & 3 \\
\hline $\begin{array}{l}\text { Чукотский } \\
\text { автономный } \\
\text { округ }\end{array}$ & 2052,43 & 2 & 76,69 & 4 & 516,11 & 1 & 29,88 & 12 & 799,6 & 1 \\
\hline
\end{tabular}


Д. Б. Дугаржапова. Восточные территории России: диспропорции развития и механизмы государственной поддержки

\begin{tabular}{|l|c|c|c|c|c|c|c|c|c|c|}
\hline $\begin{array}{l}\text { Республика } \\
\text { Бурятия }\end{array}$ & 227,1 & 12 & 64,35 & 10 & 72,23 & 12 & 392,67 & 6 & 561,0 & 11 \\
\hline $\begin{array}{l}\text { Забайкальский } \\
\text { край }\end{array}$ & 279,71 & 11 & 70,64 & 7 & 81,55 & 11 & 476,18 & 4 & 621,0 & 6 \\
\hline $\begin{array}{l}\text { Иркутская об- } \\
\text { ласть }\end{array}$ & 651,87 & 6 & 82,50 & 2 & 150,02 & 7 & 1087,91 & 1 & 646,2 & 5 \\
\hline
\end{tabular}

Источник: Данные РИА Рейтинг. URL: https://riarating.ru/infografika/20200602/630170513.html (дата обращения: 12.09.2020).

Анализ отраслевой структуры экономики исследуемых регионов показал, что экономическое развитие исследуемого макрорегиона во многом зависит от запасов природных ресурсов и функционирования транспортной инфраструктуры. Так, например, в 2017 г. в Сахалинской области, Якутии и ЧАО доля экономической деятельности по разделу «добыча полезных ископаемых» в структуре ВРП составила более $40 \%(60,48,2$ и 43,5\% соответственно), а в России - $12,1 \%$. Значительный рост данного вида экономической деятельности отмечен также в Магаданской области $(38,4 \%)$. В Приморском, Хабаровском, Забайкальском краях транспортные услуги и обслуживание экспортно-импортных потоков играют повышенную роль в ВРП (21,1, 20,2 и 19,8\% соответственно).

За 2015-2018 гг. валовой региональный продукт показал положительную динамику практически по всем субъектам Дальнего Востока и Байкальского региона (табл. 3). Тем не менее темпы роста ВРП исследуемого макрорегиона - самые низкие среди федеральных округов и составляют в среднем $15,3 \%$.

Таблица 3

Валовой региональный продукт за 2015-2017 гг., млрд руб.

\begin{tabular}{|l|c|c|c|c|c|}
\hline \multicolumn{1}{|c|}{ Регионы РФ } & 2015 г. & 2016 г. & 2017 г. & 2018 г. & $\begin{array}{c}2018 \text { г. к } \\
2015 \text { г., раза }\end{array}$ \\
\hline Республика Саха (Якутия) & 747,6 & 862,7 & 916,6 & 1084,6 & 1,5 \\
\hline Камчатский край & 175,4 & 197,1 & 201,6 & 236,4 & 1,3 \\
\hline Приморский край & 717,6 & 739,2 & 777,8 & 834,0 & 1,2 \\
\hline Хабаровский край & 595,8 & 627,4 & 666,0 & 710,6 & 1,2 \\
\hline Амурская область & 277,4 & 271,1 & 266,1 & 301,1 & 1,1 \\
\hline Магаданская область & 125,8 & 148,4 & 157,6 & 170,7 & 1,4 \\
\hline Сахалинская область & 837,5 & 748,7 & 771,2 & 1179,7 & 1,4 \\
\hline Еврейская автономная область & 44,6 & 46,0 & 52,6 & 55,8 & 1,3 \\
\hline Чукотский автономный округ & 61,7 & 67,7 & 68,7 & 78,1 & 1,3 \\
\hline Республика Бурятия & 202,8 & 198,2 & 201,6 & 226,1 & 1,1 \\
\hline Забайкальский край & 247,7 & 277,1 & 300,7 & 326,9 & 1,3 \\
\hline Иркутская область & 1001,7 & 1066,4 & 1192,1 & 1392,9 & 1,4 \\
\hline
\end{tabular}

Источник: данные Росстата. URL: https://rosstat.gov.ru/bgd/regl/b19_14p/Main.htm (дата обращения: 18.09.2020).

Отметим, что рост душевого ВРП в исследуемых субъектах происходит в основном за счет сокращения численности населения. Так, за 2010-2018 гг. в большинстве регионов наблюдается убыль населения (уменьшение по макроре- 
гиону в целом на 204 тыс. чел.). Наибольшая убыль населения за последние 8 лет наблюдается в Хабаровском (-22), Приморском (-51) и Забайкальском (-40) краях, Амурской (-35) и Иркутской (-30) областях. Прирост населения отмечен только в Бурятии (11 тыс. чел.) и Якутии (9 тыс. чел.).

В 2018 г. самыми густонаселенными регионами являлись Иркутская область (2398 чел.), Приморский (1902 чел.), Хабаровский (1321 чел.) и Забайкальский (1066 чел.) края. Средняя продолжительность жизни субъектов макрорегиона составляет 69,8 года и не достигает средней по стране (72,9 года). Общий коэффициент интенсивности миграции отрицательный во всех регионах, кроме ЧАО (48 чел.). Наиболее значимое отрицательное значение этого коэффициента в Магаданской (-187 чел.) и Еврейской автономной (-111 чел.) областях.

Уменьшение численности населения связано в первую очередь с более тяжелыми жилищными условиями, чем в других регионах Российской Федерации. Удаленность от центральной части России, суровые климатические условия также не способствуют росту населения исследуемого макрорегиона. В целом плотность населения на 1 км ${ }^{2}$ колеблется от 0,1 до 12,1 чел. и составляет в среднем 1,4.

За 2010-2018 гг. рост среднедушевых денежных доходов населения макрорегиона был выше среднего по России на $11,1 \%$ и составил 186,1\%. Тем не менее в пяти субъектах исследуемого макрорегиона денежные доходы населения не превышают среднероссийского значения. Увеличение размера оплаты труда работников и пенсий повлияло на уменьшение численности малообеспеченного населения. Так, например, наибольшее снижение произошло в Магаданской области (на 4,1\%) и Хабаровском крае (на 3,7\%). При этом реальные доходы выросли только в Камчатском крае (на 1,9\%), Сахалинской (на 6,9\%), Магаданской (на $0,6 \%$ ) и Амурской (на 2\%) областях. В целом анализ основных показателей свидетельствует о низком уровне жизни населения исследуемого макрорегиона (табл. 4).

Таблица 4

Уровень жизни населения восточных территорий РФ за 2010 и 2018 гг.

\begin{tabular}{|c|c|c|c|c|c|c|c|c|c|c|}
\hline \multirow[t]{2}{*}{ Регионы } & \multicolumn{2}{|c|}{$\begin{array}{c}\text { Реальные дохо- } \\
\text { ды населения (в } \\
\text { \% к пред. г.) }\end{array}$} & \multicolumn{2}{|c|}{$\begin{array}{c}\text { Денежные дохо- } \\
\text { ды в среднем на } \\
\text { душу населения } \\
\text { (тыс. руб.) }\end{array}$} & \multicolumn{2}{|c|}{$\begin{array}{c}\text { Оплата } \\
\text { труда в } \\
\text { среднем за } \\
\text { месяц (тыс. } \\
\text { руб.) }\end{array}$} & \multicolumn{2}{|c|}{$\begin{array}{c}\text { Числ-ть } \\
\text { населения с } \\
\text { ден. дох. } \\
\text { ниже ПМ } \\
\text { (\%) }\end{array}$} & \multicolumn{2}{|c|}{$\begin{array}{l}\text { Средний } \\
\text { размер } \\
\text { назнач. } \\
\text { пенсий } \\
\text { (тыс. руб.) }\end{array}$} \\
\hline & 2010 & 2018 & 2010 & 2018 & 2010 & 2018 & 2010 & 2018 & 2010 & 2018 \\
\hline$P \Phi$ & 105,4 & 101,1 & 18,9 & 33,2 & 20,9 & 43,7 & 12,5 & 12,6 & 7,6 & 13,3 \\
\hline $\begin{array}{l}\text { Республика } \\
\text { Саха (Якутия) }\end{array}$ & 102,9 & 102,4 & 23,1 & 42,7 & 28,7 & 68,8 & 19,0 & 18,6 & 10,4 & 18,0 \\
\hline $\begin{array}{l}\text { Камчатский } \\
\text { край }\end{array}$ & 103,2 & 105,1 & 27,0 & 48,8 & 35,7 & 73,9 & 19,5 & 15,8 & 11,8 & 20,4 \\
\hline $\begin{array}{l}\text { Приморский } \\
\text { край }\end{array}$ & 105,5 & 103,8 & 17,3 & 34,6 & 21,9 & 42,2 & 16,3 & 13,9 & 7,7 & 13,6 \\
\hline $\begin{array}{l}\text { Хабаровский } \\
\text { край }\end{array}$ & 104,7 & 101,5 & 22,5 & 39,1 & 22,7 & 47,2 & 15,9 & 12,2 & 8,8 & 15,4 \\
\hline $\begin{array}{l}\text { Амурская об- } \\
\text { ласть }\end{array}$ & 100,4 & 102,4 & 14,3 & 30,9 & 21,2 & 42,3 & 23,7 & 15,6 & 7,6 & 13,5 \\
\hline
\end{tabular}


Д. Б. Дугаржапова. Восточные территории России: диспропорции развития и механизмы государственной поддержки

\begin{tabular}{|l|c|c|c|c|c|c|c|c|c|c|}
\hline $\begin{array}{l}\text { Магаданская } \\
\text { область }\end{array}$ & 103,8 & 104,4 & 27,8 & 59,8 & 36,6 & 85,6 & 13,6 & 9,5 & 12,0 & 20,7 \\
\hline $\begin{array}{l}\text { Сахалинская } \\
\text { область }\end{array}$ & 97,8 & 104,7 & 30,7 & 53,8 & 35,8 & 77,5 & 11,0 & 8,5 & 10,1 & 17,8 \\
\hline $\begin{array}{l}\text { Еврейская } \\
\text { автономная } \\
\text { область }\end{array}$ & 103,5 & 99,6 & 15,3 & 24,7 & 19,7 & 39,2 & 19,5 & 23,7 & 7,3 & 13,0 \\
\hline $\begin{array}{l}\text { Чукотский } \\
\text { автономный } \\
\text { округ }\end{array}$ & 106,0 & 104,3 & 38,1 & 78,8 & 46,9 & 98,9 & 10,3 & 8,8 & 13,8 & 23,5 \\
\hline $\begin{array}{l}\text { Республика } \\
\text { Бурятия }\end{array}$ & 102,5 & 97,8 & 14,3 & 24,1 & 18,0 & 36,0 & 19,2 & 19,1 & 7,1 & 12,4 \\
\hline $\begin{array}{l}\text { Забайкальский } \\
\text { край }\end{array}$ & 103,2 & 102,1 & 14,2 & 24,0 & 18,7 & 40,7 & 19,0 & 21,4 & 6,9 & 12,4 \\
\hline $\begin{array}{l}\text { Иркутская } \\
\text { область }\end{array}$ & 100,8 & 100,3 & 15,1 & 24,4 & 20,5 & 42,6 & 18,1 & 17,7 & 7,8 & 13,7 \\
\hline
\end{tabular}

Источник: Регионы России. Социально-экономические показатели. 2019: Р32: стат. сб. / Росстат. М., 2019. 1204 с.

Незначительные изменения значений коэффициента Джини и коэффициента фондов за последние 10 лет свидетельствуют о сохранении ситуации неравенства в распределении доходов в регионах. Так, например, в 2018 г. разница в доходах между группами населения с наименьшими и наибольшими доходами достигала свыше 10 раз, коэффициент Джини в среднем составил 0,385. В свою очередь, дифференциация уровня доходов населения усиливает неравенство потребления материальных благ, услуг образования и здравоохранения [2].

Сложившаяся ситуация влечет за собой масштабный отток населения с депрессивных территорий в благополучные регионы. За 2010-2018 гг. в исследуемом макрорегионе наблюдается снижение численности рабочей силы на $3,6 \%$ (на 203 тыс. чел.). На этом фоне отмечается рост численности работников госорганов и органов местного самоуправления (МСУ) на 27,8\%, территориальных органов исполнительной власти на 67,3 \% (табл. 5).

Таблица 5

Основные показатели рынка рабочей силы Дальнего Востока и Байкальского региона за 2010 и 2018 гг. (тыс. чел.)

\begin{tabular}{|c|c|c|c|c|c|c|c|c|c|c|}
\hline \multirow[t]{2}{*}{ Регионы РФ } & \multicolumn{2}{|c|}{$\begin{array}{c}\text { Численность } \\
\text { работников } \\
\text { гос. органов } \\
\text { и органов } \\
\text { МСУ }\end{array}$} & \multicolumn{2}{|c|}{$\begin{array}{c}\text { Численность } \\
\text { работников } \\
\text { терр.-х орга- } \\
\text { нов исполн. } \\
\text { власти }\end{array}$} & \multicolumn{2}{|c|}{$\begin{array}{l}\text { Численность } \\
\text { работников в } \\
\text { органах МСУ }\end{array}$} & \multicolumn{2}{|c|}{$\begin{array}{c}\text { Численность } \\
\text { раб. силы }\end{array}$} & \multicolumn{2}{|c|}{$\begin{array}{l}\text { Численность } \\
\text { безработных }\end{array}$} \\
\hline & 2010 & 2018 & 2010 & 2018 & 2010 & 2018 & 2010 & 2018 & 2010 & 2018 \\
\hline ДФО & 170,8 & 218,2 & 69,4 & 116,1 & 50,4 & 50,7 & 5705 & 5502 & 550 & 361,2 \\
\hline $\begin{array}{l}\text { Иркутская об- } \\
\text { ласть }\end{array}$ & 33,3 & 42,3 & 11,6 & 20,4 & 11,2 & 11,5 & 1263 & 1184 & 133 & 89,3 \\
\hline
\end{tabular}

Источник: Данные Росстата. URL: https://rosstat.gov.ru/folder/210/document/13204 (дата обращения: 12.09.2020). 
Таким образом, неравномерное социально-экономическое развитие рассматриваемых регионов способствует территориальной дифференциации исследуемого макрорегиона и выступает источником социальной напряженности в различных локально-территориальных общностях внутри регионов, способствуя сохранению диспропорций пространственного развития исследуемого макрорегиона.

Механизмы и результаты государственной поддержки развития дальневосточных территорий

В рамках снижения уровня социально-экономической дифференциации и ускорения экономического развития регионов восточных территорий используются различные инструменты государственной поддержки, одним из которых являются территории опережающего развития (ТОСЭР) [4; 6]. Территории призваны стимулировать инвестиционную деятельность, способствовать формированию благоприятного делового климата и решению демографических проблем макрорегиона.

По данным Министерства РФ по развитию Дальнего Востока и Арктики в 2019 г. на территории Дальнего Востока создано 20 ТОСЭР и зарегистрировано 403 резидента. Общий объем инвестиций составил свыше 2 трлн руб., создано более 69 тыс. рабочих мест (табл. 6).

Таблица 6

Результаты деятельности территорий опережающего развития за 2015-2019 гг.

\begin{tabular}{|l|c|c|c|c|c|}
\hline \multicolumn{1}{|c|}{ Показатель } & 2015 & 2016 & 2017 & 2018 & 2019 \\
\hline Количество ТОСЭР, ед. & 9 & 14 & 18 & 18 & 20 \\
\hline Количество привлеченных резидентов, ед. & 21 & 111 & 204 & 330 & 403 \\
\hline Инвестиции, млрд руб. & 187 & 450 & 2175 & 2337 & 2821 \\
\hline Созданные рабочие места, ед. & 7666 & 22256 & 39772 & 56813 & 69865 \\
\hline
\end{tabular}

Источник: Официальный сайт Министерства РФ по развитию Дальнего Востока и Арктики (Минвостокразвития). URL: https://minvr.gov.ru/activity/territorii-operezhayushchego-razvitiya (дата обращения: 12.09.2020).

За последние 5 лет количество привлеченных резидентов увеличилось в 19,2 раза. Произошел рост объемов инвестиций резидентов ТОСЭР в 15,1 раза, количества созданных рабочих мест — в 9,1 раза. По итогам 2019 г. введено в эксплуатацию 110 новых предприятий в различных сегментах территориальноотраслевой структуры хозяйства, в реализацию которых вложено 100 млрд руб., создано 11,5 тыс. новых рабочих мест ${ }^{1}$. Сложившаяся ситуация свидетельствует об устойчивом тренде увеличения территорий опережающего развития на Дальнем Востоке.

Каждая территория опережающего развития имеет свою отраслевую специализацию в силу местоположения и ресурсного потенциала территории. В основ-

\footnotetext{
${ }^{1}$ Социально-экономическое развитие Дальневосточного федерального округа: годовой отчет о ходе реализации и оценке эффективности государственной программы РФ за 2019 год [Электронный ресурс]. URL: https://minvr.gov.ru/upload/iblock/3ca/soprovod-_otchet-2019-god.pdf (дата обращения: 13.09.2020).
} 

государственной поддержки

ном представлены такие отрасли, как добыча полезных ископаемых, судостроение и судоремонт, животноводство и растениеводство, рыболовство, а также обрабатывающая промышленность и транспортно-логистические предприятия.

Всем зарегистрированным резидентам ТОСЭР Дальнего Востока предоставляются налоговые льготы (табл. 7).

Таблица 7

Сравнение налоговых ставок

\begin{tabular}{|c|c|c|}
\hline Перечень & Для резидентов ТОСЭР & $\begin{array}{l}\text { Не рези- } \\
\text { дентов }\end{array}$ \\
\hline Налог на прибыль & $0-12 \%$ & $20 \%$ \\
\hline $\begin{array}{l}\text { Налог на имуще- } \\
\text { ство }\end{array}$ & $0-1,1 \%$ & $2,2 \%$ \\
\hline Налог на землю & 0 \% - 0-3 года & $1,5 \%$ \\
\hline $\begin{array}{l}\text { Социальные от- } \\
\text { числения }\end{array}$ & $\begin{array}{c}7,6 \%-\text { в течение } 10 \text { лет } \\
(6-\text { в ПФП; } 1,5-\text { ФСС; } 0,1-\text { ТФОМС }) \\
\end{array}$ & $30 \%$ \\
\hline $\begin{array}{l}\text { Налог на добычу } \\
\text { полезных иско- } \\
\text { паемых }\end{array}$ & $\begin{array}{l}\text { Для применения льготы на прибыль применяется нулевой по- } \\
\text { нижающий коэффициент к налогооблагаемой базе; применя- } \\
\text { ется понижающий коэффициент на базу НДПИ с начала приме- } \\
\text { нения льготной ставки по налогу на прибыль: } \\
\text { От } 0 \text { до } 2 \text { лет, К=0; } \\
\text { От } 2 \text { до } 4 \text { лет, К=0,2; } \\
\text { От } 4 \text { до } 6 \text { лет, К=0,4; } \\
\text { От } 6 \text { до } 8 \text { лет, К=0,6; } \\
\text { От } 8 \text { до } 10 \text { лет, К=0,8; } \\
\text { От } 10 \text { и более лет, К=1 }\end{array}$ & $8 \%$ \\
\hline
\end{tabular}

Источник: Официальный сайт Агентства Дальнего Востока по привлечению инвестиций и поддержке экспорта [Электронный ресурс]. URL: https://investvostok.ru/services/gos-help (дата обращения: 13.09.2020).

Также резидентам предоставляются и административные преференции, включая сокращенные сроки проведения контрольных проверок, предоставление земельного участка для размещения производства, режим «одного окна» для инвестора, защита управляющей компанией в суде [5].

Согласно данным ФНС России, общая сумма налогов резидентов ТОСЭР на 2019 г. составила 715,46 млн рублей, сумма неуплаченного налога - 4,21 млрд руб. Сложившаяся ситуация может быть обусловлена инвестиционными вложениями резидентов на указанных территориях. Так, например, за 2015-2018 гг. наибольший рост инвестиций отмечается в Якутии и в Амурской области, что связано прежде всего с развитием предприятий по добыче полезных ископаемых, их переработкой в Якутии и наличием Транссибирской магистрали и международных транспортных коридоров, способствующих эффективному функционированию логистических и транспортных компаний в Амурской области.

Вместе с тем не все территории опережающего развития, расположенные в субъектах Дальнего Востока и Байкальского региона, показывают положительную динамику по вводу инвестиций в основной капитал (табл. 8). 
Инвестиции в основной капитал за 2015-2018 гг., млрд руб.

\begin{tabular}{|l|c|c|c|c|c|}
\hline \multicolumn{1}{|c|}{ Регионы РФ } & 2015 & 2016 & 2017 & 2018 & $\begin{array}{c}2018 \text { г. к } \\
2015 \text { г., } \\
\text { раза }\end{array}$ \\
\hline Республика Саха (Якутия) & 198,03 & 275,58 & 386,79 & 403,43 & 2,04 \\
\hline Камчатский край & 22,85 & 37,30 & 39,01 & 39,28 & 1,72 \\
\hline Приморский край & 139,21 & 130,50 & 130,94 & 141,86 & 1,02 \\
\hline Хабаровский край & 114,01 & 120,09 & 121,19 & 129,65 & 1,14 \\
\hline Амурская область & 102,21 & 129,82 & 192,47 & 239,71 & 2,35 \\
\hline Магаданская область & 60,67 & 41,80 & 43,89 & 51,51 & 0,85 \\
\hline Сахалинская область & 241,46 & 240,01 & 211,82 & 218,34 & 0,90 \\
\hline Еврейская автономная область & 12,01 & 12,93 & 11,04 & 16,82 & 1,40 \\
\hline Чукотский автономный округ & 14,63 & 12,76 & 12,50 & 15,07 & 1,03 \\
\hline Республика Бурятия & 36,22 & 33,45 & 42,21 & 48,75 & 1,35 \\
\hline Забайкальский край & 76,28 & 85,70 & 96,32 & 90,06 & 1,18 \\
\hline Иркутская область & 206,08 & 247,95 & 270,02 & 316,40 & 1,54 \\
\hline
\end{tabular}

Источник: Данные Росстата. URL: https://rosstat.gov.ru/bgd/regl/b19_14p/Main.htm (дата обращения: 14.09.2020).

Причиной этому могут быть малое число резидентов, недостаточность средств в силу низкой рентабельности предприятий, непривлекательность отрасли, географическая отдаленность и пр.

Существенными факторами, затрудняющими сбалансированное развитие субъектов рассматриваемого макрорегиона, являются неразвитость социальной, энергетической и транспортной инфраструктур [1;3]. Так, например, в Магаданской области высокие тарифы на электроэнергию на фоне избытка энергетических мощностей, высокие транспортные и производственные издержки выступают в качестве слабых сторон социально-экономического развития региона.

В рамках преодоления инфраструктурных ограничений в 2019 г. из федерального бюджета было выделено 4732,2 млн руб. Согласно данным Фонда развития Дальнего Востока и Арктики, в 2019 г. инвестиции в инфраструктурные и промышленные проекты в макрорегионе выросли на 54 \% (до 16,4 млрд руб.). Всего с 2015 по 2019 г. фондом заключены инвестиционные соглашения по реализуемым проектам на сумму 59,6 млрд руб., предоставлено финансирование на сумму свыше 50 млрд руб. в 20 отраслевых проектах общей стоимостью более 500 млрд рублей. На сегодняшний день из 20 проектов с объемом инвестиций фонда 6,6 млрд руб. реализованы три. Деньги возвращены в полном объеме. Общий объем возвратов по всем проектам составил 14 млрд рублей.

В целях снижения межрегиональной дифференциации и технологического развития секторов экономики макрорегиона средства федерального бюджета в рамках государственных программ в основном распределяются по четырем направлениям (табл. 9). 
Д. Б. Дугаржапова. Восточные территории России: диспропорции развития и механизмы государственной поддержки

Таблица 9

Направления расходов на реализацию госпрограмм на 2018-2021 гг.

\begin{tabular}{|l|c|}
\hline \multicolumn{1}{|c|}{ Направления } & Объем финансирования, \% \\
\hline «Новое качество жизни» (10 госпрограмм) & 14,3 \\
\hline $\begin{array}{l}\text { «Инновационное развитие и модернизация экономики» } \\
\text { (14 госпрограмм) }\end{array}$ & 31,0 \\
\hline «Обеспечение национальной безопасности» (2 госпрограммы) & 3,9 \\
\hline «Сбалансированное региональное развитие» (3 госпрограммы) & 50,7 \\
\hline Итого & 1,3 трлн руб. \\
\hline
\end{tabular}

Источник: Доклад о комплексном развитии регионов Дальнего Востока // Министерство Российской Федерации по развитию Дальнего Востока и Арктики (Минвостокразвития) [Электронный ресурс]. URL: https://minvr.gov.ru/opened-ministry/doklad-o-kompleksnom-razvitii-dalnego-vostoka (дата обращения: 15.09.2020).

По итогам реализации мероприятий госпрограммы в 2019 г. рост промышленного производства наблюдается в девяти дальневосточных субъектах (от $+112,3 \%$ в Магаданской области до $+101,6 \%$ в Сахалинской области).

Тем не менее, несмотря на положительную динамику ВРП практически по всем субъектам Дальнего Востока и Байкальского региона, представленную в таблице 10, темпы его роста остаются все же достаточно низкими среди федеральных округов и составляют в среднем $15,3 \%$. Отметим, что рост душевого ВРП в исследуемых субъектах происходит в основном за счет сокращения численности населения.

Таблица 10

Динамика валового регионального продукта за 2015-2017 гг., млрд руб.

\begin{tabular}{|l|c|c|c|c|c|}
\hline \multicolumn{1}{|c|}{ Регионы РФ } & 2015 г. & 2016 г. & 2017 г. & 2018 г. & $\begin{array}{c}2018 \text { г. к } \\
2015 \text { г., раза }\end{array}$ \\
\hline Республика Саха (Якутия) & 747,6 & 862,7 & 916,6 & 1084,6 & 1,5 \\
\hline Камчатский край & 175,4 & 197,1 & 201,6 & 236,4 & 1,3 \\
\hline Приморский край & 717,6 & 739,2 & 777,8 & 834,0 & 1,2 \\
\hline Хабаровский край & 595,8 & 627,4 & 666,0 & 710,6 & 1,2 \\
\hline Амурская область & 277,4 & 271,1 & 266,1 & 301,1 & 1,1 \\
\hline Магаданская область & 125,8 & 148,4 & 157,6 & 170,7 & 1,4 \\
\hline Сахалинская область & 837,5 & 748,7 & 771,2 & 1179,7 & 1,4 \\
\hline Еврейская автономная область & 44,6 & 46,0 & 52,6 & 55,8 & 1,3 \\
\hline Чукотский автономный округ & 61,7 & 67,7 & 68,7 & 78,1 & 1,3 \\
\hline Республика Бурятия & 202,8 & 198,2 & 201,6 & 226,1 & 1,1 \\
\hline Забайкальский край & 247,7 & 277,1 & 300,7 & 326,9 & 1,3 \\
\hline Иркутская область & 1001,7 & 1066,4 & 1192,1 & 1392,9 & 1,4 \\
\hline
\end{tabular}

Источник: Данные Росстата [Электронный ресурс]. URL: https://rosstat.gov.ru/bgd/regl/b19_14p/ Main.htm (дата обращения: 12.09.2020).

\section{Заключение}

Таким образом, формирующиеся тенденции и ориентиры потенциального развития ТОР свидетельствуют прежде всего о положительных сторонах прово- 
димой политики в преобразовании территориально-отраслевой структуры хозяйства рассматриваемых регионов за счет ввода в эксплуатацию новых предприятий, расширения их спектра, появления новых рабочих мест и т. д.

Тем не менее проведенный анализ основных макроэкономических показателей свидетельствует о неравенстве и существенных диспропорциях социальноэкономического развития субъектов восточных территорий РФ. Отличия исследуемых субъектов по экономической специализации, наличии ресурсного потенциала, динамике экономических и социальных показателей, уровню жизни, экономическим процессам, характерным для территории, оказывают влияние на уровень региональных различий. В результате существующие дисбалансы обусловливают социальную напряженность в различных локально-территориальных общностях внутри регионов. В свою очередь, недостаточность финансовых ресурсов у региональных властей определяет низкую степень свободы в части проведения регионами собственной социально-экономической политики. В этой связи необходима значительная корректировка государственной региональной политики в области снижения неравенства и улучшения социально-экономического положения регионов.

В целом непродолжительный период функционирования дальневосточных ТОСЭР делает преждевременным оценку эффективности их влияния на решение накопленных социально-экономических проблем субъектов исследуемого макрорегиона.

\section{Литература}

1. Козлова О. А., Терентьева Т. В., Макарова М. Н., Лан Д. Х. Территориальные факторы стратегического развития Дальневосточных регионов // Экономика региона. 2016. T. 12, № 3. C. 765-775.

2. Козырева П. М., Смирнов А. И. Масштабы и динамика социально-экономического неравенства в современной России // Россия реформирующаяся: ежегодник / отв. ред. M. К. Горшков. М.: Новый Хронограф, 2018. Вып. 16. С. 290-318. DOI: 10.19181/ezheg.2018.13.

3. Левин Ю. А., Павлов А. О., Прокопьев П. С. Новая модель развития Дальнего Востока: изменение финансовой архитектуры региона // Инновации и инвестиции. 2018. № 12. С. 260-263.

4. Мирзеханова 3. Г. Территории опережающего развития российского Дальнего Востока: ожидания и действительность // Региональные проблемы. 2019. Т. 22, № 2. С. 5561. DOI: 10.31433/2618-9593-2019-22-2-55-61.

5. Прокофьев С. Е., Елесина М. В. Роль человеческого потенциал в контексте перехода к инновационному социально ориентированному типу экономического развития // Муниципальная академия. 2018. № 3. С. 70-78.

6. Сериков С. Г. Практика применения программно-целевого планирования в региональной экономической политике по развитию российского Дальнего Востока // Региональная экономика: теория и практика. 2018. Т. 16, № 5. С. 90-911. 


\section{EASTERN TERRITORIES OF RUSSIA: \\ DEVELOPMENT IMBALANCES AND STATE SUPPORT MECHANISMS}

Dolgorma B. Dugarzhapova

Cand. Sci. (Econ.), Senior Researcher,

Buryat Scientific Center SB RAS

8 Sakhyanovoy St., Ulan-Ude 670047, Russia

dolgor@mail.ru

Abstract. The article analyzes the main macroeconomic indicators. It has been found that there is an inequality and significant disproportions in the development of the eastern territories of Russia. We have emphasized the key problems that cause the emergence of imbalances in the spatial development of the studied macroregion. It is noted that the existing imbalances generate the tension in various local communities within the regions.

We consider the implementation of priority development areas as a measure of state support for the economic development of the macroregion. It is emphasized that the emerging trends and guidelines for the potential development of the studied territories attests to the positive aspects of the policy pursued in transforming spacial and sectoral structure of the economy of Russia's eastern regions.

It is shown that the ongoing outflow of population in most of the Far Eastern regions, high infrastructure costs necessitate additional support measures with the refinement of approaches to the organization of settlement system, development of social infrastructure, transport and budget financing using mechanisms of interbudgetary subsidies.

Keywords: Far East; Baikal region; socio-economic development; economic differentiation; governmental support; priority development areas.

Статья поступила в редакцию 14.10.2020; одобрена после рецензирования 30.10.2020; принята к публикации 30.10.2020. 